\title{
O processo criativo de Karim Aïnouz: o movimento da imagem em criação
}

\author{
Aline Vaz \\ Doutoranda; Universidade Tuiuti do Paraná, Curitiba, PR, Brasil \\ alinevaz900@gmail.com \\ Tarcis Prado Júnior \\ Doutor; Universidade Tuiuti do Paraná, Curitiba, PR, Brasil \\ tarcisjr@yahoo.com.br
}

\section{Resumo}

O presente estudo busca refletir a partir de depoimentos do cineasta brasileiro Karim Aïnouz a sua própria visão sobre o ato criativo da obra cinematográfica que produz. Olhando para a obra bibliográfica, 2013, e para as entrevistas gravadas e disponibilizadas no YouTube, pelo Cinema da Universidade de São Paulo - Paulo Emílio (CINUSP), em 2013, e pelo Centro Audiovisual Norte-Nordeste (Canne), em 2014, considera-se Aïnouz um interveniente em todos os processos do fazer fílmico. O cineasta é um roteirista, um diretor de elenco, um realizador, um editor de som e um montador que se preocupa em manter o processo de criação em pulsão e o roteiro como um mapa de voo transformador. O movimento de suas imagens nasce da vivacidade do caminho da criação em que cada etapa é vista com a emoção daquilo que se torna urgente em prol de sua realização.

\section{Palavras-chave}

Cinema. Teoria dos Cineastas. Karim Aïnouz. Processo Criativo.

\section{Introdução}

Discorrer sobre o cinema é também pensar que o fazer fílmico acarreta uma perspectiva teórica dos cineastas, considerando que “[...] a obra de arte é aquilo que foi criado por um indivíduo que tem um projeto." (AUMONT, 2004, p. 08) e observando que "[...] 
o cineasta é um homem que não pode evitar a consciência de sua arte, a reflexão sobre seu ofício e suas finalidades, e, em suma, o pensamento." (AUMONT, 2004, p. 07).

Os pesquisadores André Rui Graça, Eduardo Tulio Baggio e Manuela Penafria, no artigo Teoria dos cineastas: uma abordagem para a teoria do cinema (2015), apresentam conceitos prévios, problematizações, objetivos, metodologia geral e possibilidades de investigação no âmbito da pesquisa. Para tal abordagem torna-se imprescindível a análise a partir da originalidade e autoria do cineasta que irá desembocar na ideia de criação, pressupondo que ele reflete teoricamente sobre sua obra, pois sem a reflexão não poderia ser original e nem estabelecer um estilo.

Seguindo sugestões de consultas do artigo Teoria dos cineastas: uma abordagem para a teoria do cinema, reorganizamos, brevemente, a filmografia e selecionamos entrevistas de Karim Aïnouz, propondo conhecer e divulgar o modo do realizador de pensar o cinema - o seu cinema -, dando destaque ao processo de criação, pressupondo a contribuição de Aïnouz para um panorama mais vasto em relação à teoria do cinema ${ }^{1}$. Desse modo, a pesquisa se torna emergente ao passo que o cineasta selecionado pensa sua obra durante todo o processo fílmico. Desde a ideia do roteiro até sua finalização na montagem: Aïnouz revela-se um roteirista, um editor de som e montador, um diretor de atores, um realizador e um cineasta que se dispõe a falar e pensar sobre o seu cinema em suas possibilidades de criação, olhares, encontros e acidentes, sem minimizar a coletividade do fazer fílmico - o trabalho com a equipe e o respeito para com o espectador.

Em outubro de 2012, Karim Aïnouz foi o convidado do 1ํe encontro do Ficção Viva II - O Roteiro Cinematográfico, projeto curitibano que em sua segunda edição trouxe à cidade, além de Aïnouz, os cineastas Guillermo Arriaga (México), Kleber Mendonça Filho (Brasil), Miguel Gomes (Portugal), Lucrecia Martel (Argentina) e Carlos Reygadas (México). A convite do projeto, os cineastas realizaram workshops, exibiram seus filmes e conversaram com o público no período entre outubro de 2012 e junho de 2013.

Fruto do referido encontro, que teve parceria da Petrobras, os coordenadores do Ficção Viva, Marcelo Munhoz e Rafael Urban, organizaram o livro Conversas sobre uma Ficção Viva (2013). Desta edição nasceu a transposição das conversas com os cineastas,

\footnotetext{
${ }^{1}$ As fontes sugeridas pelo estudo Teoria dos cineastas: uma abordagem para a teoria do cinema (2015) são: o próprio filme, que não deve ser ofuscado por outras leituras, e interpretações da obra; leitura atenta de todo material escrito pelo cineasta; contato com entrevistas, depoimentos, manifestações verbais do cineasta; reorganização e classificação da filmografia cronológica do cineasta, e acesso a filmes que nunca foram finalizados, mas que tenham a produção de algum material, como roteiro, por exemplo.
} 
tratando de questões provocadoras sobre o roteiro cinematográfico e da cinematografia ibero-americana contemporânea, enfim, o fazer fílmico da concepção inicial à feitura.

Em debate realizado no dia 18 de abril de 2013, após a pré-estreia do filme Abismo Prateado, o cineasta Karim Aïnouz e a atriz Alessandra Negrini, que interpreta a protagonista Violeta, participaram do debate CINUSP, realizado no cinema da Universidade de São Paulo (USP), que na ocasião foi palco da exibição cinematográfica e da conversa que norteou o processo de criação do filme, aproximando a obra, o cineasta, a atriz e os espectadores.

Em 2014, Karim Aïnouz esteve no Seminário Narrativas Audiovisuais Contemporâneas, realizado pelo Centro Audiovisual Norte-Nordeste (Canne), fruto de uma parceria da Fundação Joaquim Nabuco (Fundaj) - vinculada ao Ministério da Educação (MEC) - com a Secretaria do Audiovisual do Ministério da Cultura (SAv/MinC). O Canne foi implantado em 2008 como parte da Massangana Multimídia Produções, produtora audiovisual da Fundaj, com o objetivo de criar um espaço para oferta de bens de produção cinematográfica e um centro de formação profissional na área do audiovisual. Em 2014, o Canne passou a atuar na pesquisa, no registro e compartilhamento de processos de criação audiovisual com a realização do Seminário Narrativas Audiovisuais Contemporâneas. A primeira temporada da série explorou o roteiro cinematográfico, por meio de debates com realizadores e roteiristas sobre seus processos criativos, incluindo Aïnouz.

A partir da obra bibliográfica Conversas sobre uma Fiç̧ão Viva (2013) e as entrevistas gravadas e disponibilizadas no YouTube pelo CINUSP, em 2013 e o Canne, em 2014, propomos um elo intercomunicante entre as conversas transpostas de Karim Aïnouz e a sua produção cinematográfica, incitando questões a respeito do seu processo criativo, concebido desde os roteiros até o procedimento de montagem.

\section{Karim Aïnouz: o cineasta}

Karim Aïnouz nasceu no estado brasileiro do Ceará, no ano de 1966, e mudou-se para Berlim, na Alemanha, em 2003. O cineasta graduou-se em Arquitetura pela Universidade de Brasília e é mestre em Teoria do Cinema pela Universidade de Nova Iorque. No começo dos anos 1990, trabalhou nos Estados Unidos como assistente de direção e montador de filmes. Aïnouz atuou no Departamento de Câmera e Elétrica no filme Veneno 
(Todd Haynes; 1991), no qual também foi diretor de elenco. No Departamento Editorial, trabalhou nos filmes Veneno (Todd Haynes; 1991), Swoon - Colapso do desejo (Tom Kalin; 1992) e Ambição em alta voltagem (Allen Hughes, Albert Hughes; 1995). Dirigiu os longasmetragens Madame Satã (2002), O céu de Suely (2006), Viajo porque preciso, volto porque te amo (2009), O abismo prateado (2011), Praia do futuro (2014) e os curtas O preso (1992), Seams (1993), Paixão nacional - Choque metabólico irreversível (1996), Hic habitat felicitas (1996), Les ballons des bairros (1998), Rifa-me (2000), Sertão de acrílico azul piscina (2004), Sunny lane (2011) e Domingo (2015).

Como montador, Aïnouz trabalhou em Paixão nacional - Choque metabólico irreversível (1996). Foi produtor associado de Cinema, aspirinas e urubus (2005) e produtor executivo de Tá (2007). Também, roteirizou os longas-metragens Abril despedaçado (2001), Madame Satã (2002), Cinema, aspirinas e urubus (2005), Cidade baixa (2005), O céu de Suely (2006), Viajo porque preciso, volto porque te amo (2009) e Praia do futuro (2014).

Em 2014, participou como diretor e roteirista ao lado de outros diretores, incluindo Wim Wenders, no projeto de filme 3D sobre a alma dos edifícios, intitulado Catedrais da cultura. Na televisão dirigiu com Sérgio Machado a série Alice (2008), que deu origem à direção do filme televisivo Alice: o primeiro dia do resto da minha vida (2010). Ainda na tevê, com Marcelo Gomes, diretor com o qual já havia trabalhado em outros projetos, incluindo Viajo porque preciso, volto porque te amo (2009), dirigiu o curta-metragem Gentilândia park, parte da série Short plays (2014), idealizada por Daniel Gruener, que reuniu cerca de 30 diretores. Em 2015, dirigiu o documentário Diego Velázquez ou le réalisme sauvage, o qual roteirizou junto de Marcelo Gomes e de Yves Nilly.

Pelo seu primeiro longa-metragem, Madame Satã (2002), recebeu mais de 40 prêmios nacionais e internacionais. Já o filme $O$ céu de Suely (2006), entre os mais de 50 prêmios recebidos, foi vencedor do Festival de Havana. O abismo prateado (2011) venceu o Festival do Rio na categoria Première Brazil, na indicação de Melhor Diretor e no Festival de Havana venceu nos prêmios de Melhor Atriz (Alessandra Negrini), Melhor Trilha Sonora (Waldir Xavier, Ricardo Cutz e Leandro Lima), Melhor Cinematografia (Mauro Pinheiro Jr.) e Segundo Prêmio Coral (Karim Ainouz). Praia do futuro (2014) também recebeu prêmios e indicações, incluindo o prêmio do Festival Internacional de San Sebastián, da Espanha, e a disputa pelo Urso de Ouro no Festival de Berlim².

\footnotetext{
2 Listamos apenas os filmes lançados até o momento no Brasil (aos quais tivemos acesso): não ignoramos, por exemplo, que seu novo filme A Vida Invisível de Eurídice Gusmão, foi selecionado para a competição oficial do Festival de Cannes 2019, na mostra Un Certain Regard.
} 
Sempre disposto a falar de sua produção e do procedimento criativo, no evento realizado pelo Canne (2014), Karim Aïnouz definiu a existência de três roteiros no processo de criação de um filme: 1) o texto desenvolvido quando está pensando o filme, com formatação, descrições, diálogos ou não; 2) aquele que surge no momento de filmagem e coloca-se como outro roteiro em sua execução em campo; e 3) o roteiro que passa a existir na montagem, tornando-se o ato de escrever sem palavras.

Partindo dessa divisão, observaremos adiante o roteiro como um mapa de voo, o roteiro em seus possíveis encontros e acidentes durante a filmagem e o roteiro sendo construído e desconstruído durante a montagem. Nesses três momentos de criação de um filme, surgirá o Aïnouz roteirista, o Aïnouz diretor de som e montador, o Aïnouz diretor de elenco, o Aïnouz realizador: um Aïnouz cineasta.

Partimos do pressuposto que Karim Aïnouz considera o cinema como potência de aproximação aos riscos. 0 grau de risco existe em todos os seus filmes desde o processo de criação até a construção de seus personagens, que são pessoas sem medo - a ausência do medo da vida está presente em todos os seus filmes. Neste artigo, escolhemos o relato do próprio cineasta em relação à produção de seus filmes, citando diretamente as obras Seams (1993), Madame Satã (2002), O céu de Suely (2006), O abismo prateado (2011) e Praia do futuro (2014). Percebe-se que os protagonistas aceitam os riscos impostos pelas possibilidades do movimento que a vida proporciona, movimentos arriscados na tela do cinema.

Em O céu de Suely (2006), no retorno migratório de São Paulo para Iguatu, a personagem Hermila evidencia as transformações de uma volta que nunca pode ser preenchida com o que já foi. No deslugar (FISCHER, 2012), Hermila não se identifica com a paisagem, não compreende, não possui, "des-habita" a cidade, faz o processo migratório de retorno, mas é assolada pelo desconforto e estranhamento que encontra no seu lugar que não é mais.

[...] é alguém que não está dentro, não está fora, não está entre dentro e fora; que não pertence pertencendo e que pertence sem pertencer; alguém que é mas não é. 0 sujeito pode, preenche todas as condições que lhe facultam ocupar determinada posição, mas a ela não se acomoda. É o ser sem ser. (FISCHER, 2012, p. 04). 
Sandra Fischer (2012, p. 04) complementa: "não é, tampouco, exclusividade do âmbito familiar; mas, talvez, uma de suas fontes de origem seja a família: é nesse contexto, parece, que o deslugar tende a instalar-se preferencialmente." A casa da avó de Hermila coloca a personagem no deslugar, uma casa que apenas recolhe, sem acolher. Na primeira noite do retorno, o filho chora dentro da casa - aparentemente acolhido, mas desconfortável. A mãe, Hermila, ouve o choro no lado externo, ignorando a presença da casa, do choro, do pertencimento à família, do filho que irá pertencer àquela casa sem ela. 0 espaço de Hermila vai ser habitado em algum lugar longe de Iguatu. Ela cumpre sua passagem na cidade que evidencia o despertencimento e inicia uma nova viagem, em busca de uma paisagem que se torne espaço. Em uma atitude arriscada, mas generosa, deixa o filho encontrar seu próprio canto no mundo (BACHELARD, 1978) na casa da avó. Quem vive em deslugar é Hermila, a partida é solitária, o risco de ir é a única coisa que lhe pertence.

Nos primeiros minutos do filme $O$ abismo prateado (2011), conhecemos o personagem que mergulha no mar e em seguida caminha pela cidade. Ela deixa o mar e dá as costas para as ondas, olha para o seu próximo destino, a cidade: o enquadramento não permite que a olhemos para a verticalização dos prédios, vemos apenas luzes em meio à escuridão da praia, luzes que não clareiam a visão, mas desfocam o olhar. Trajando roupa de banho, Djalma caminha na rua tomada por transeuntes. Entre moradores apressados, vestidos em suas rotinas que nada tem a ver com um banho de mar, a personagem não pertence ao lugar pelo qual caminha, está desconfortável, é grande demais para poder habitar a praia que é engolida pela cidade.

Essa personagem que se joga ao mar em busca de ar é um homem grande, grande demais para a praia urbana, é preciso fugir da maldição do tédio, pois "se nossas relações ainda não são aquelas que gostaríamos de desenvolver; “[...] tendemos a imaginar maquinações hostis, complôs, conspirações de um inimigo que se encontra em nossa porta ou embaixo de nossa cama." (BAUMAN, 2009, p. 15). É preciso arriscar-se na partida, abandonar a casa e permitir-se pertencer ao risco do longe que detém tudo aquilo que pode vir a ser.

Em Praia do futuro (2014), a personagem de Wagner Moura, Donato, é um salvavidas em Fortaleza (Ceará). Ele conhece Konrad, um alemão pelo qual se apaixona. A personagem também se arrisca, deixa a casa, a mãe, o afeto do irmão caçula e aventura-se na partida, arrisca-se deixando tudo para trás e em busca de uma história de amor ainda em prenúncio, de um pertencer em outro lugar. Anos depois Ayrton também se arrisca em 
busca do irmão Donato no novo país. As idas são deslocamentos afetivos sem hesitações, não há medo no ir potencializado no afeto dos encontros com o provável e o desconhecido. Também, percebe-se que em Praia do futuro não há hesitação do cineasta que escolhe narrar o tema da homossexualidade, ainda tabu para uma sociedade exposta aos discursos de ódio amparados em preconceitos propulsores de diversas violências; é um risco escolhido e filmado por Aïnouz: constata-se que seu cinema se torna bem-sucedido ao passo em que se arrisca.

\subsection{O processo criativo do fazer fílmico: planejamento, filmagem e montagem}

Como brevemente mencionado, para Karim Aïnouz há três momentos no processo do fazer fílmico: o planejamento, em que se pensa e escreve o roteiro; a filmagem e os seus imprevistos em suas dinâmicas e leis internas; e a montagem, um momento sem retorno às duas fases anteriores e que encerra os filmes para o diretor, que detesta assistir a eles depois de prontos. A preocupação de Aïnouz com o roteiro surge da necessidade em encontrar a clareza emocional da cena. Para ele o roteiro é um termômetro para medir o coração da cena, se tem sentido ou se é apenas didática, tornando possível excluir o desnecessário e possibilitando ao cineasta mudar de ideia no set com a clareza que o roteiro permite em sua simplicidade e sem maquiagens.

Em Conversas sobre uma Ficção Viva (2013), Aïnouz esclarece que o roteiro em sua finalização é apenas um detalhe, o que realmente parece ser indispensável é o processo pensar na personagem, em seus modos de agir, seus movimentos, conversar sobre isso e redesenhar as ideias iniciais, olhar para as possibilidades de recriá-lo com mais nitidez. 0 roteiro estrutural deve criar possibilidades de documentar aquilo que o ator está interpretando. O roteiro não é uma verdade absoluta, é um processo passível de transformações e que deve ser compartilhado e discutido. 0 processo de roteirizar um filme deve passar por diálogos com outras pessoas, é o momento de confrontar as ideias. Afastando um conceito de roteirização introspectiva, Aïnouz, encara a criação do roteiro como uma etapa de debate, um mapa de voo em direção a um processo de filmagem.

Durante o workshop do $1^{\mathrm{o}}$ encontro do Ficção Viva II, Karim Aïnouz exibiu o filme que deu início a sua carreira: Seams (1993), realizado aos seus 26 anos de idade, que partiu de certa necessidade pessoal, um filme feito para ninguém ver. Em sua feitura não havia o 
questionamento sobre se alguém o veria ou não, mas aos poucos foi sendo compreendido como um objeto que talvez pudesse afetar algumas pessoas, vindo a ser uma experiência compartilhada. 0 roteiro de Seams é posterior ao processo de captação de imagem e de som feito sem nenhum objetivo especifico, assim como podemos observar no processo de produção de Sertão de acrílico azul piscina (2004), em que Aïnouz gravou planos que gostava e passou a montar o filme a partir dessas captações, as quais deram origem ao documentário e, mais tarde, ao filme de ficção Viajo porque preciso, volto porque te amo (2009). 0 realizador adverte que mesmo num processo posterior, o roteiro é um elemento organizador que transforma o filme em um discurso. Para ele o roteiro surge como uma ressignificação de algo, questionando o que levará o espectador a olhar para aquilo: a técnica, a tensão, o mistério e as inúmeras possibilidades que instigam o olhar curioso.

Ainda no encontro do Ficção Viva, Karim Aïnouz analisa duas cenas, fala como elas foram filmadas e como foram finalizadas no processo de montagem. Percebe-se o que ecoou do roteiro inicial e o que se transformou no processo do fazer fílmico. A primeira cena analisada pertence ao $10^{\circ}$ tratamento de Madame Satã (2002), reescrita logo antes da filmagem e, mais uma vez, reescrita depois de um ensaio com os atores.

Madame Satã é um filme biográfico sobre João Francisco dos Santos, um transformista brasileiro, personagem emblemático da vida noturna e marginal carioca da primeira metade do século XX. A cena abordada pelo diretor é basicamente um diálogo em que o Madame Satã foge da polícia e reencontra Renatinho. A conversa do roteiro está a rigor quase toda na finalização da montagem. A movimentação é sugerida no roteiro, mas foi filmada com muito mais liberdade. Karim Aïnouz revela que a cena foi preparada por muitos anos, uma cena que lhe era muito clara e necessária ao filme. No momento da filmagem, ele percebe que a única coisa que poderia aproveitar da cena roteirizada eram os diálogos e o resto viria ao encontro da câmera. Para o cineasta, era preciso respeitar a energia dos atores que "Pareciam umas pipocas, eles ficavam pulando dentro do espaço." (AÏNOUZ, 2013, p. 45).

A montadora de Madame Satã estava no set, o que possibilitava que as cópias fossem reveladas na segunda-feira e na quarta-feira já estivessem montadas. A troca de olhares para o filme proporcionava encontrar soluções para coisas que estavam no roteiro e que no momento da filmagem não davam certo, e outras que escritas pareciam distantes de serem filmadas, mas que eram bem-sucedidas. Segundo Aïnouz (2013, p. 48), a personagem era caótica, filmá-la era arrumar o impossível. Para o cineasta, uma linda cena precisa "arrumar 
este impossível" (2013, p. 48, grifo nosso), mas isso não pode estar escrito no roteiro, “arrumar a bagunça” (2013, p. 48, grifo nosso) seria uma alternativa mais sensata e filmável.

Para Karim Aïnouz é o planejamento do roteiro e sua clareza que o permite ter o caos necessário no encontro com a filmagem. Para o cineasta é importante que a estrutura do roteiro não seja a mesma da montagem, se as cenas permanecerem iguais é porque nada aconteceu no tempo entre a escrita e a filmagem. É preciso levantar questões e ir mudando, é preciso encontrar a vida e o processo imponderável do cinema, daí a necessidade de partir da estrutura ao caos e "arrumar o impossível", mesmo que no roteiro esteja escrito "arrumar a bagunça".

Nota-se que a estrutura do roteiro nunca fica na montagem, mas é importante filmar com uma estrutura clara. As personagens devem ser compreendidas, é preciso saber o que elas querem e, a partir disso, o cineasta pode fazer o que ele quiser. 0 cinema é dinâmico de desejo e a personagem tem que querer algo. Quando a equipe está consciente dos desejos da personagem ela consegue criar cenas. Outro ponto explicitado pelo cineasta é a importância de o espectador entender o que está sendo contato num filme, mas sem que seja necessário explicar o que está acontecendo, é preciso criar maneiras de o espectador intuir, acompanhar e se apropriar da trajetória da personagem. Em $O$ céu de Suely (2006), faz-se necessário compreender que Hermila tem que ir embora, ela não poderia simplesmente dizer que precisa ir embora. 0 filme precisa respeitar o desejo da personagem e as inferências do espectador.

A cena de $O$ céu de Suely, analisada por Karim Aïnouz no workshop, foi ensaiada várias vezes e filmada em duas ou três posições de câmeras diferentes. A cena no roteiro tem quatro personagens: como protagonistas da cena, Suely e a avó, e como coadjuvantes, a tia e o filho. A avó está com raiva da neta e dá vários tapas que não estremecem a personagem, a qual se mantém firme sem pedir perdão ao deixar a avó enfurecida. Ao olhar para o neto, Rosário hesita, Suely sai, com raiva, bate a porta de casa e a avó se senta tremendo no sofá. Na versão final o filho e a tia já não ocupam a cena e os nomes das personagens mudam. A cena foi ensaiada várias vezes, a filmagem teve duas ou três posições de câmera diferentes e a atriz levou vários tapas na cara. 0 diálogo foi apropriado e improvisado pelas atrizes no momento dos ensaios. 0 roteiro funcionou como um ponto de partida, mas Aïnouz revela que em nenhum momento impôs uma prisão ao texto, pois era necessário entender a dinâmica das atrizes. 
No roteiro, após essa cena, Suely vai encontrar uma amiga, mas na filmagem o diretor percebeu que não poderia fazer essa sequência. Depois de uma cena tensa não era possível partir para uma cena de duas pessoas falando, seria um desrespeito com o filme e com a personagem. 0 que aconteceu foi que a atriz, exausta, perguntou se o dia havia acabado e Aïnouz respondeu que sim. Segundo o relato do diretor, ela estava com o rosto vermelho, transtornada, saiu da casa, acocorou e começou a chorar. Perversamente, nas palavras do cineasta, ele pediu para que o fotógrafo filmasse a atriz Hermila Guedes. Nesse momento ele quebra o contrato com a atriz; para ela o dia havia acabado, mas ele continuou a filmá-la. Quando percebeu ela ficou nervosa e saiu andando. Aïnouz pediu para que o fotógrafo a seguisse até acabar o negativo. Essa é a cena que existe no filme e esse é o caos que Karim Aïnouz fala que é necessário haver para organizar o impossível de um filme.

Para ele deve haver um planejamento de filmagem no roteiro, mas é indispensável encontrar as possibilidades no set, que podem dar certo ou não - é a sua tarefa estar alerta para documentar tudo o que é importante emocionalmente para a situação da cena. Aqui podemos fazer relação com o conceito de pequenas crises de Hans Gumbrecht (2006) sobre as rupturas na ordinariedade do cotidiano que fazem emergir novas reflexões e caminhos, ou mesmo proporcionar momentos epifânicos. Essa pequena crise provocada pela condição emocional da atriz estafada pelo final do seu dia de trabalho, apontou um novo caminho de percepção para que Aïnouz desenvolvesse uma nova perspectiva de uma cena, captando aspectos realistas daquela performance que, de outra forma, dificilmente teria obtido. A quebra da rotina por essas fissuras, ou, nos termos de A. J. Greimas (2002) fraturas ${ }^{3}$, leva então o diretor a pensar em formas de transformar o acidental em material fílmico materialização estética e estésica.

Na conversa do CINUSP (2013) o cineasta Karim Aïnouz e a atriz Alessandra Negrini, intérprete da protagonista de $O$ abismo prateado (2011), responderam questões sobre o filme após a exibição. 0 cineasta inicia o debate revelando o processo atípico de produção que ocorreu em relação ao tempo levado para produzir o filme entre a proposta do produtor em março de 2010 e a finalização do filme em 2011, fugindo do padrão de suas produções, as quais sempre levaram alguns anos para serem finalizadas.

\footnotetext{
30 conceito de fratura foi cunhado por Greimas (2002) e significa a ruptura, a fissura na ordem cotidiana que provoca algum sentimento até então velado, escondido. Em outras palavras, trata-se de um acontecimento externo e acidental que causa um alumbramento, uma espécie de epifania. Essa ideia remete a Gumbrecht (2006) com as pequenas crises, denotando momentos de interrupção das isotopias cotidianas, proporcionando, dessa forma, experiências estéticas, o que podemos aproximar do processo de criação de Karim Aïnouz que, buscando "arrumar o inesperado", constrói na potência "acidental” a relação com a estética e suas possibilidades estésicas no processo de realização de um filme.
} 
Adaptação da música de Chico Buarque, Olhos nos olhos (1976), O abismo prateado narra a trajetória de Violeta, que após ser abandonada pelo marido recebe apenas uma mensagem de voz comunicando sobre a partida. Ela tenta sair do labirinto que se dá no olhar deformado pelo trauma do abandono - vive dentro de um abismo entre o concreto dos edifícios e das estradas que não guiam caminhos, da movimentação instável do mar que não permite navegações e desempenha significado decorativo para os habitantes com olhares desatentos, que não vivenciam as experiências do espaço como área de lazer e sim de passagem. Logo, em um processo intuitivo, tanto na roteirização quanto na montagem, o desejo do cineasta era sempre mostrar onde que terminava a natureza e onde começava a civilização.

Beatriz Bracher, que escreveu o roteiro, é uma autora literária - desse modo o texto tomou um tom mais poético que clássico, possibilitando maior liberdade na filmagem e traduzindo-se num 'outro' na finalização do filme. Aïnouz revela que havia uma cena no roteiro em que a personagem perfurava a poltrona com uma faca, houve o ensaio com seis poltronas, eram seis takes. Segundo o diretor, no papel, a cena descrita era linda, mas na filmagem não funcionava do mesmo modo, havia algo errado. A locação tinha um jardim de inverno e o cineasta teve a ideia de que a personagem começaria a espalhar as plantas dentro de casa - esta é a cena vista no filme finalizado: a personagem tentando "arrumar o impossível".

Aïnouz afirma que sempre irá reescrever o filme na montagem, por exemplo, o plano do mar, que abre $O$ abismo prateado (2011), no roteiro estava originalmente no final. Ao inserir a cena no início cria-se a sugestão de um desastre que virá adiante, significado acolhido junto ao título do filme, o qual aponta uma tragédia eminente e que, talvez, só tenha sido visualizada com nitidez durante a montagem, tornando possível o vislumbre e a provável imersão no abismo no qual Violeta mergulha em sentimentos ondulantes e perambulantes na cidade prateada pelo asfalto que acinzenta o mar em meio à urbanidade que se impõe.

O tempo da narrativa do filme acontece em 24 horas e o cuidado foi mostrar esse dia com a maior minimização de elipses possíveis, o que foi resolvido na montagem, fazendo com que tanto o tempo quanto a tensão do filme fossem traduzidos sensorialmente. Para a atriz Alessandra Negrini o filme é uma interrupção do tempo, a personagem vive sua rotina e de repente ela é "quebrada" (personagem e rotina), o que é sugerido pela respiração - a personagem tenta permanecer respirando em um lugar em que o tempo é banido, a vida 
está paralisada em meio a um movimento entorpecido, que enfatiza muito mais o "estar sem rumo" do que o "ir em direção à".

Torna-se importante citar a atriz aqui, pois, segundo Aïnouz, em $O$ abismo prateado (2011) (e não somente) foi essencial estar sempre aberto ao que os atores estavam fazendo naquele espaço e como isso se traduzia. Sabemos pelo diretor e pela atriz que a comunicação entre eles era muito íntima - havia afinamento em um trabalho colaborativo em que o diretor pode sugerir e o ator pode preencher. Negrini chama a atenção para como é atuar em um cinema autoral, no qual é preciso tentar entender a cabeça do diretor. Nesse processo de compreensão do filme torna-se fundamental penetrar no universo do cineasta. Faz-se urgente viajar no estilo do autor. Uma vez que fosse compreendida a linguagem de Karim Aïnouz, a atriz estaria livre para viajar nesse mundo cinematográfico.

No universo de $O$ abismo prateado (2011) era necessário criar uma história mais de desamor do que de amor. Era desejado falar de uma personagem comum de classe média e transformá-la em uma heroína. Segundo Aïnouz, a classe média é mediana porque ela tem medo que algo dê errado e saia do controle, proporcionando que a narrativa crie um discurso preenchido pela falta nessa fratura da vida estável. Não gratuitamente é importante pensar no ano de sua realização - 2010 - considerar o retrato do seu tempo, o retrato de um cinema que se permite entrar em um território que não se fazia urgente anteriormente e que se dá a ver na tela do cinema justamente em um período do Brasil em que a classe média cresce e é preciso compreendê-la (ao menos construir tentativas de reflexões). Se em Madame Satã o cineasta sentia a necessidade de falar de uma personagem marginalizada, quase uma década depois, com a ascensão da classe média, Aïnouz sentiu a necessidade de mostrar que, também, poderia falar de uma personagem integrada à sociedade em crescimento econômico.

Para encerrar o olhar de Karim Aïnouz no processo de criação de $O$ abismo prateado, não nos esqueçamos de que o som foi muito importante nesse processo de criação de um filme de sensações. Existe o descolamento da personagem, desfocando o fundo e focando no som, elementos essencialmente do cinema experimentados como elementos narrativos. Aqui, vale ressalvar que desde o primeiro filme, Aïnouz, trabalhou com o mesmo montador de som, Waldir Xavier, cineasta que se destaca em sua carreira de montador, incluindo o filme Central do Brasil (1998) e sua atuação com o cineasta Pedro Costa. A parceria entre Aïnouz e Xavier é sempre um trabalho com o som e com a dramaturgia. Para Aïnouz a sonoridade é um elemento narrativo importantíssimo; mais que a palavra. Seus filmes são 
sempre montados com possibilidades distintas de som. Muita coisa é mudada na mixagem, atentando para o fato de o diretor prezar pelo ruído de sala mais alto do que se mixa geralmente, pois para ele é onde se faz uma conexão com o corpo da personagem.

Em Praia do futuro (2014), filme discutido no Seminário Narrativas Audiovisuais Contemporâneas (2014), organizado pelo Canne, Karim Aïnouz fala do acidente cinematográfico que pode se dar entre o roteiro e a preparação. No filme protagonizado por Wagner Moura, quando o irmão mais novo vai atrás de Donato, ele o encontra limpando um aquário, o que não estava presente no roteiro. Durante a pesquisa de locação as questões do homem que foi embora, que foi em busca de outra vida - quais seriam as permanências e rupturas - estavam muito em carne viva, pois segundo o diretor o que tinham no roteiro não era tão bom. Passando por um hotel que Aïnouz não conhecia e que o diretor de arte fez algumas fotos do aquário e lhe mostrou, o lugar logo entrou no filme. Percebe-se que os acidentes não se dão na escrita, o roteiro é um planejamento que precisa manter um mistério e tornar-se uma caligrafia própria; o roteiro se faz uma organização que precisa ser desconstruída e reorganizada diariamente na filmagem (e na montagem), mantendo a realização fílmica algo vivo, trazendo alumbramento, algo acidental inerente às pequenas fraturas do cotidiano que permitem construir e encontrar a beleza sensível do cinematográfico.

Praia do futuro tem três capítulos - mas no roteiro eram quatro -, criando um equilíbrio entre a personagem de Donato e o irmão. 0 primeiro capítulo começava com o irmão mais novo, anterior à viagem para a Alemanha, depois cortava e tinha o segundo capítulo de Donato, o afogamento e todo o encontro com o alemão, o terceiro capítulo era a vida deles na Alemanha e o quarto capítulo estava centrado no o presente, revelando o encontro dos irmãos. Essa versão durou dois anos, mas os flashbacks incomodavam o cineasta. Então, o primeiro capítulo foi retirado, pois para Aïnouz o filme que se chamava Praia do futuro deveria andar para o futuro, sem o movimento de idas e vindas no tempo.

Outro motivo pelo qual o roteiro teve muitas alterações foi pelo fato de que a Alemanha foi filmada primeiro e a filmagem no Brasil teve um intervalo de seis meses em função de questões climáticas no Ceará, que no ano das filmagens foi surpreendido por muitas chuvas. Nesse intervalo Aïnouz montou o material da Alemanha e reescreveu o que estava previsto para gravar no Brasil. A cena de sexo no carro, no roteiro era um encontro, um beijo, um jantar e então uma noite de amor. Aïnouz observou que a vida não acontecia assim e quando acontece é sem graça. $\mathrm{O}$ amor entre Donato e Konrad é um amor romântico, 
em que o afeto se dá pelo encontro físico. Para o cineasta a nova cena filmada foi um risco que ajudou muito a equipe a entender o que fazer a partir daquilo, tal como uma libertação.

Enfim, observa-se que em todos os filmes revelados em seus processos de produção, desde o roteiro até a preocupação com a liberdade dos atores, com a imersão do espectador e a reorganização sem palavras do roteiro na montagem, Karim Aïnouz preocupa-se em manter o processo em pulsão, manter sua criação viva e estar aberto a transformar as estratégias. 0 processo de criação precisa estar em movimento, afinal, fazer cinema é também criar movimento.

\section{3 (In)conclusões}

Considerando que o fazer fílmico está constituído de reflexões, do modo de olhar e ser olhado para e pelo o cinema, o presente estudo acompanha o pensamento de Karim Aïnouz pelos seus depoimentos, seu olhar para o próprio processo criativo, com foco no roteiro, um mapa de voo que percorre todo o procedimento do fazer fílmico com a liberdade de movimentar-se, transformar e tornar-se outro, sentindo o que cada cena precisa para manter-se viva em todas as etapas: a pulsão da cena é sentida em cada momento, respeitada em seu instante de escrita, exposta às diversas trocas comunicacionais no momento de discutir o que se pensa, que pode modificar-se na etapa de filmagem em que é preciso habitar o set na troca de energia com a equipe e, ainda, a revelação de um novo olhar na fase da montagem, em que é preciso se desvencilhar do planejamento escrito e criar outra perspectiva para o filme em seu resultado filmado, que deixa de ser a idealização de estratégias escritas, para tornar-se matéria lançada ao mundo, oferecendo possibilidades de significações ao espectador, que olha e é olhado para e pela tela do cinema. Ou seja, pode-se afirmar que o cineasta está aberto à experiência estética nos termos de Gumbrecht (2006) quando submete seu processo criativo à própria dinâmica inesperada e acidental de seu trabalho, já que:

a vida comum [no contexto do "profissional de cinema"], nas mais simples situações, pode suscitar momentos em que a rotina é quebrada por objetos, cores, formas, barulhos, sensações - enfim, movimentos sinestésicos que podem proporcionar experiências estéticas das quais as pessoas sempre se recordarão (PRADO JÚNIOR; CARDOSO; IACOMINI JÚNIOR, 2018, p. 145). 
Logo, pensando em todas as crises, fraturas e construções estéticas e estésicas que partem do jogo sensível durante a produção fílmica, olhando de perto para um cineasta que busca captar toda a experiência de filmar, o artigo torna-se breve, ainda ponderando que o pensamento do cineasta é algo livre e em constante transformação, assim como a sua obra. A tentativa da atual pesquisa é criar um ponto de partida como base para futuros estudos a respeito de uma coerência de pensamento, organizada pelas manifestações verbais e cinematográficas do cineasta. Em suma, podemos observar o olhar vivo do realizador sobre sua obra, que exalta um processo criativo de constantes encontros que proporcionam o movimento às imagens de seu discurso cinematográfico, um discurso que trabalha com o risco da criação - as pequenas crises de Gumbrecht (2006); as fraturas de Greimas (2002) e seus significantes lançados aquém e além da tela do cinema.

\section{Referências}

AÏNOUZ, Karim. Roteiro: um mapa de voo. In: MUNHOZ, Marcelo; URBAN, Rafael (Org.). Conversas sobre uma ficção viva. Curitiba: Imagens da terra, 2013.

AUMONT, Jacques. As teorias dos cineastas. Campinas: Papirus Editora, 2004.

BACHELARD, Gaston. Os pensadores. São Paulo: Abril Cultural, 1978.

BAUMAN, Zygmunt. Confiança e medo na cidade. Rio de Janeiro: Zahar, 2009.

CANNE. Narrativas Audiovisuais Contemporâneas - Temp.01 Ep. 01 - Karim Aïnouz. 1 vídeo (19 min). Disponível em: https://www.youtube.com/watch?v=Bq-Xqgj_LXo. Acesso em: 26 jan. 2015.

CANNE. Narrativas Audiovisuais Contemporâneas - Temp.01 Ep.02 - Karim Aïnouz. 1 vídeo (20 min). Disponível em: https://www.youtube.com/watch?v=CnJTxb2z3s0. Acesso em: 26 jan. 2015.

CINUSP. Pré-Estréia - Debate "O Abismo Prateado" com Karim Aïnouz e Alessandra Negrini. 1 vídeo (68 min). Disponível em: https://www.youtube.com/watch?v=dejg_LKHqwQ. Acesso em: 26 jan. 2015.

GRAÇA, André Rui; BAGGIO, Eduardo Tulio; PENAFRIA, Manuela. Teoria dos cineastas: uma abordagem para a teoria do cinema. Revista Científica/FAP, Curitiba, v.12, p. 19-32, 2015.

GREIMAS, Algirdas Julius. Da Imperfeição. São Paulo: Hacker Editores, 2002. 
GUMBRECHT, Hans. Pequenas crises: experiência estética nos mundos cotidianos. In: GUIMARAES, César; LEAL, Bruno Souza; MENDONÇA, Carlos Camargos. (org.).

Comunicação e experiência estética. Belo Horizonte: Editora UFMG, 2006.

FISCHER, Sandra. Deslugar e deslocamento em O Palhaço: imagens de transe e trânsito.

Revista Interin, Curitiba, v. 12, n. 2, 2012.

MADAME Satã. Direção: Karim Aïnouz. Brasil. 2002. DVD (105 min).

MUNHOZ, Marcelo; URBAN, Rafael. Conversas sobre uma ficção viva. Curitiba: Imagens da terra, 2013.

O CÉU de Suely. Direção: Karim Aïnouz. Brasil. 2006. DVD (88 min).

O ABISMO Prateado. Direção: Karim Aïnouz. Brasil. 2011. DVD (83 min).

PRAIA do Futuro. Direção: Karim Aïnouz. Alemanha; Brasil. 2014. DVD (106 min).

PRADO JÚNIOR, Tarcis; CARDOSO, Moises; IACOMINI JÚNIOR, Franco. Experiência estética no debate do filme Lakay numa universidade brasileira. In: Galáxia, São Paulo, n. 38, p. 140$153,2018$.

SEAMS. Direção: Karim Aïnouz. Brasil. 1993 (30 min).

SERTÃo de acrílico azul piscina. Direção: Karim Aïnouz; Marcelo Gomes. Brasil. 2004 (26 $\min )$.

VIAJO porque preciso, volto porque te amo. Direção: Karim Aïnouz; Marcelo Gomes. Brasil. 2009. DVD (75 min).

\title{
Karim Aïnouz's creative process: the movement of the image in creation
}

\begin{abstract}
This research stems from Karim Ainouz's testimonies to reflect on his vision about the creative act in his cinematographic production. By analyzing the book Conversas sobre uma Fiç̧ão Viva (2013) and the interviews conceded by Ainouz - recorded and made available on YouTube by the São Paulo University Paulo Emílio (CINEUSP), in 2013, as well as by the Centro Audiovisual Norte-Nordeste (Canne), in 2014 -, we consider him as an active participant in the whole process of filmmaking. The Brazilian director is a screenwriter, a casting director, a maker, a sound editor, and an assembler. He worries about keeping the creative process in pulse and makes of the script a
\end{abstract}


map of a transforming flight. The movement of his images emerges from the vivacity of the creative journey, in which every step is seen with the emotion of what becomes urgent on behalf of its realization.

\section{Keywords}

Cinema. Filmmakers' Theory. Karim Aïnouz. Creative Process.

Recebido em 28/04/2019

Aceito em 24/07/2019 